an experiment which anyone can make, taking ordinary care to avoid fallacies. These and many other considerations show that alcohol lowers vital action, though it may apparently stimulate indirectly through relaxation of bloodvessels. We come back to the point that in such a condition the body is less fortified against the attacks of erysipelas or any other disease. The returns of the London Grand Division of the Sons of Temperance for 1890, notwithstanding the influenza epidemic, show an average sickness of seven days per member. The most temperate users of alcohol cannot beat that. I trust that Mr. Whitehead will further investigate the subject, and see what the standard works on alcohol really say.

$$
\text { I am, Sirs, yours truly, }
$$

J. J. RIDGE,

Enfield, March 16th, $1891 . \quad$ Hon. Sec., Brit. Med. 'Temp. Assoc.

${ }^{*}{ }^{*}$ The correspondence on this subject must now cease. ED. $\mathbf{L}$.

\section{ARREST IN GENERAL PARALYSIS.}

\section{To the Editors of THE LANCET.}

SIRS,-Recently there have been under my observation three successive cases of general paralysis, in each of which "arrest" has taken place; all were strong men and in the prime of life. The symptoms were unmistakable; indeed, they were typical of the disease. I need hardly give them in detail, they are well known. The firet patient believed himself King of Heaven and Earth, and made princes and dukes of those around him; he made millions of money daily, and invited the Prince of Wales and the Duke of Cambridge to dine with him. The second was violent, fought and resisted at first; he made two hundred thousand pounds a day, and offered to make the fortune of all indiscriminately at once; he squandered his money and wrote cheques recklessly. The third was maniacal ; he shouted incessantly and was violent, he had thrown knives about, he was King of the World, he had inherited millions under successive wills, and spent most of his time, from his lofty elevation, in watching and controlling the revolutions of the earth.

In each of these cases there were pin-point, unequal, or irregular pupils, the usual great excitement of the first stage, the tilthy habits, the restlessness, the sleeplessness, the loss of flesh, the tremulous movements of lips and tongue, and the defective and drawling articulation. They each went through a longer or shorter first stage, and, finally, each in turn gradually lost the excitement, the exaltation, the delusions, the filthy habits, the restlessness, the sleeplessness, and made flesh. Coherence returned perfectly in the first two cases, the third is gradually regaining it. The mental powers, considering the strain they had gone through, were wonderfully little impaired. Each became able to transact business, to settle, manage, and put in order his own affairs. It is not improbable-indeed, it is likelythat each of these cases will again break down physically, and lose mind, but my object in seeking to draw attention to such cases is to show that it may prove of immense advantage to a patient suddenly struck down with so formidable a disease as general paralysis to practically recover, although the recovery may be only temporary, and thus have time given him to put his house in order. That such remission, arrest, or temporary recovery from the disease as I have here described may be favoured by early treatment and careful conduct of the patient through the first stage my later experience of general paralysis leads me strongly to believe.-I am, Sirs, your obedient servant,

West Malling, Kent, March 14th, 1891.

JAMES ADAM, M.D.

\section{ST. BOTOLPH'S CHURCH, ALDGATE.}

To the Editors of THE LANCET.

SIRS,-As upper warden of the church of St. Botolph, Aldgate, I cannot allow to pass without comment the condemnatory remarks you have thought fit to make upon the conduct of those concerned in the removal of the bones in the churchyard surrounding this church. The original order was varied because it was found that, in order to construct a vault as originally ordered to receive the displaced bones, other bones, probably in equal quantity, would have to be displaced. During the erection of a new heating apparatus three months ago numerous vaults containing remains were found in the floor of the crypt, and it was decided that this should be leveled and concreted. Before this could be accomplished the difficulty occurred with regard to the disposal of the bones found in the churchyard. Dr. Tristram came down and carefully inspected the premises, and ordered that the bones should be deposited in the crypt. This order has been reverently and decently carried out. The bones so collected have been sprinkled with lime and put in boxes, and each box has been covered with an inch of vegetable charcoal before being fastened down, and this has been done, not because there has been the least perceptible effluvium, but simply as a matter of precaution. The leaden coffins are placed each in a separate box in the crypt under the tower of the church, and there walled in and cemented. The bones are all dry and clean; there has not been at any time during the progress of the work any odour detected. You probably are not aware that no law exists which would permit the removal of the bones as you suggest. In order to obtain such removal nothing short of a special Act of Parliament would have been required. I think it desirable that before making public comment on such an undertaking you should make yourself personally acquainted with the circumstances. I shall be happy to show you or your representative over the church and crypt at any time by appointment. Meanwhile I shall be glad if you will cause the insertion of this letter in THE LANCET of this week.

I am, Sirs, yours faithfully, Jno. Cotman, M.R.C.P. Edin., \&e.

Minories, City, March 23rd, 1891.

\section{A NOZZLE FOR NASAL DOUCHE. To the Editors of THE LANCET.}

SIRs,-Having had some difficulty in arranging a nasal douche for a lady, I had a nozzle made for ne, which I think presents some advantages. It consists of a hollow indiarubber nose piece, which can be blown out just so as to be comfortable to the nostril. It has a central tube, into which a glass tube (connected with a syphon douche) fits. By its softness and its accurate adaptability to the nostril, it prevents escape of any lotion used, and at the same time gives the patient no discomfort.

I am, Sirs, yours obedien tly,

Russell CoOMre, M.A., F.R.C.S

West Southernhay, Exeter.

P.S.-It was manufactured by Messrs. C. Wright \& Co., of New Bond-street.

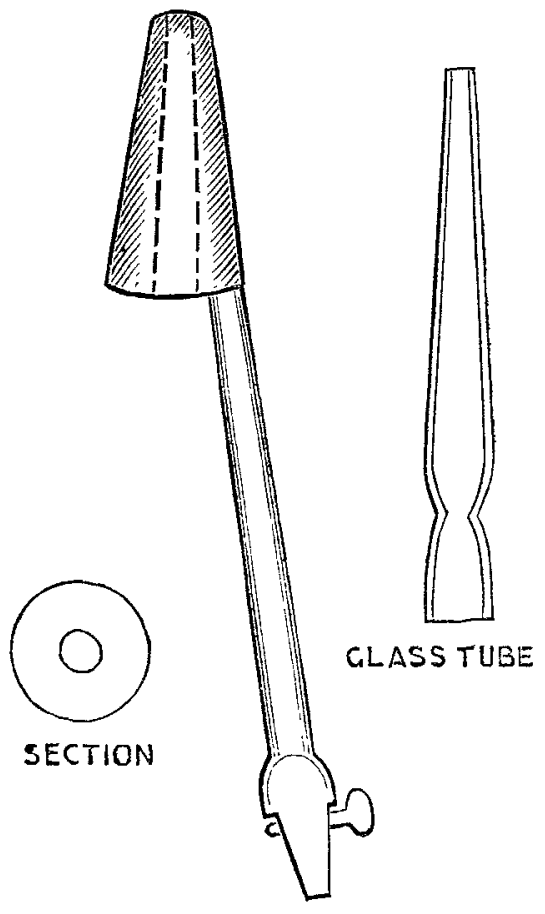

\section{THE "REST CURE" IN THE SAHARA.} (From a Holiday Corresponden't.)

THIs islet, or rather group of islets, in the great sand sea has all the makings of an admirable health resort, particularly for the sufferer from brain fag or the convalescent from neurasthenia. Its stillness, its estrangement from "the fever and the fret" of the populous European centres, its pure exhilarating atmosphere, its varied 